\title{
Granular cell tumour: An uncommon tumour of Schwann cell origin
}

\author{
Anup Kumar Tiwary, Yashwant Anant Lal, Dharmendra Kumar Mishra
}

Department of Dermatology, Venereology and Leprosy, Rajendra Institute of Medical Sciences, Ranchi, India

Corresponding author: Dr. Anup Kumar Tiwary, E-mail: anup07tunnu07@gmail.com

\begin{abstract}
Granular cell tumour is a rare soft tissue tumour of Schwann cell origin. This is usually solitary and benign but rarely can be multiple and malignant. Most commonly involved sites are tongue, skin and subcutaneous tissue but can occur at any site. Clinically, it can be misdiagnosed as dermal appendageal tumour or soft tissue tumour. Definitive diagnosis is made by histopathological examination demonstrating sheets of large polygonal or round,granular cells which are positive for S-100 on immunohistochemistry. Excisional biopsy is done as both diagnostic and curative purpose. Regular follow up is needed to look for recurrence and malignant transformation. Here we document a case of benign GCT in a 45 yrs old female.
\end{abstract}

Key words: Granular cell tumour; Schwann cell; Soft tissue tumour

\section{INTRODUCTION}

GCT is an uncommon tumour of Schwann cell origin with an incidence of $0.017 \%-0.029 \%$, first described by Abrikossoff as granular cell myoblastoma in 1926 [1-4]. It most commonly occur in tongue but can occur at any other sites presenting as an asymptomatic, solitary, flesh coloured, firm or hard nodule in middle aged persons [1]. In few cases, it can be multiple and rarely, malignant transformation has also been reported. Fine needle aspiration cytology (FNAC) or biopsy is done to obtain the sample and diagnosis is confirmed by distinctive histopathological features [2,3]. Excision with wide margin is recommended due to ill defined margins and risk of recurrence and malignancy.

\section{CASE REPORT}

A 45yrs old female presented with asymptomatic,solitary, well circumscribed, hyperpigmented, hard nodule of size $2.5 \mathrm{~cm} \times 2.5 \mathrm{~cm}$ on right side of lower part of abdomen. One year back, it appeared as asymptomatic, skin coloured, small papule which gradually increased in size over $l$ year up to the present size. Hyperkeratotic changes were seen on its surface. There was no history of trauma, infection or pre-existing dermatoses on the same site. No such family history was noted.

General physical and systemic examination was not remarkable. On local cutaneous examination, lesion was solitary, well circumscribed, hyperpigmented, dome shaped, mobile, non-tender, hard nodule (Fig. 1). There was no history of trauma, oozing or bleeding from the lesion or other cutaneous sites. Telangiectasia, ulceration or discharge was absent. Examination of mucosa, hairs, nails and teeth were also normal. Regional lymph nodes were not enlarged. All routine investigations and laboratory parameters were within normal limits and non contributory.

Excisional biopsy was done as both diagnostic and therapeutic measure. During excision, tumour was found to be ill defined and located in deep dermis with yellowish-white cut surface. It was completely excised with wide margins and specimen was sent for histopathological examination. Histopathology revealed non-encapsulated broad fascicles of tumour cells containing irregular sheets of large, round cells with indistinct borders surrounded by collagen and flattened

\footnotetext{
How to cite this article: Tiwary AK, Lal YA, Mishra DK. Granular cell tumour: An uncommon tumour of Schwann cell origin. Our Dermatol Online. 2016;7(4):409-411.

Submission: 09.02.2016; Acceptance: 02.04.2015

DOI:10.7241/ourd.20164.112
} 
fibroblasts (Fig. 2). The cells had pale cytoplasm filled with abundant eosinophilic coarse granules, centrally or eccentrically placed small oval nuclei and within few cells, eosinophilic bodies with a clear halo called as 'pustule-ovoid bodies of milian' were seen (Fig. 3). Nuclear atypia, mitoses and necrosis were not seen. Based on these distinctive histopathological features, diagnosis of GCT was made. After excisional biopsy, wound was sutured with mersilk 3-0 and after healing of the wound, patient was advised to follow up biannually.

Prior to the study, patient gave written consent to the examination and biopsy after having been informed about the procedure.

\section{DISCUSSION}

GCT is a rare soft tissue tumour, previously thought to be of muscular origin but now accepted to be originated from Schwann cell due to strong positivity for $\mathrm{S} 100$ protein expression [2-5]. The common sites of predilection are tongue, skin and subcutaneous tissue. Other less common sites are nerve, breast, scalp, abdominal wall, back, extremities, inguinal region, lymph node, mediastinum, soft palate, orbit, salivary glands, respiratory tract, vulva and GIT [1-5] In the skin, it usually presents as single, painless, mobile, well circumscribed, slow growing, skin coloured, pink or greyish, firm or hard nodule with smooth or hyperkeratotic surface located in dermis or subcutaneous layer $[1,2]$. Its size varies between $5 \mathrm{~mm}-30 \mathrm{~mm}$ with a tendency to regress partially over the time. It is more common in females of 20-50 yrs of age group and in black population. Multiple GCT's have also been reported in less than $10 \%$ cases especially in children and may be associated with certain syndromes, malformations and carcinoma namely Noonan syndrome, Watson's syndrome, osteomuscular malformations, oculofacial alterations, neurofibromatosis, squamous cell carcinoma of esophagus, adenocarcinoma of prostate and small cell lung carcinoma [6]. Most cases show benign behaviour but on rare occasion, metastatic spread has been seen in $1-2 \%$ cases suggesting malignancy [2].

It was classified by Fanburg-Smith et al. as benign, malignant and atypical on the basis of six histopathologic criteria: increased mitotic activity ( $>2$ mitoses/10 hpf at $\times 200$ magnification), high nucleo-cytoplasmic ratio, nuclear polymorphism, necrosis, spindling of tumour cells and vesicular nuclei with prominent nucleoli [7]. Tumours

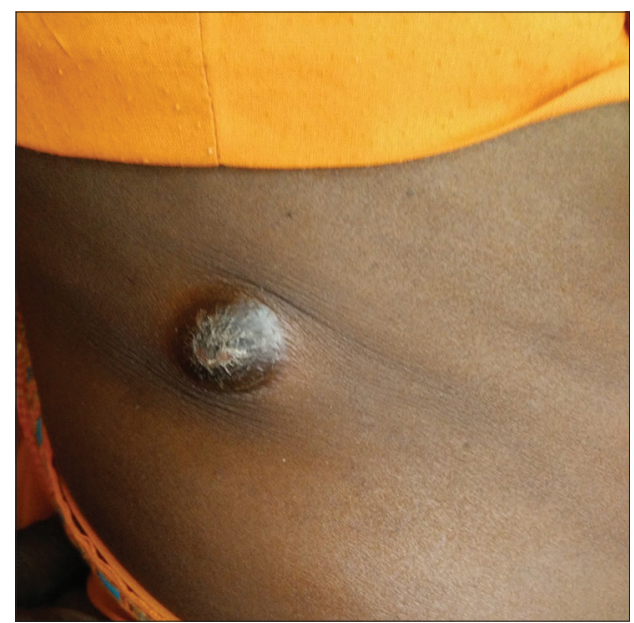

Figure 1: Non-tender, well circumscribed, hyperpigmented, dome shaped, hard nodule.

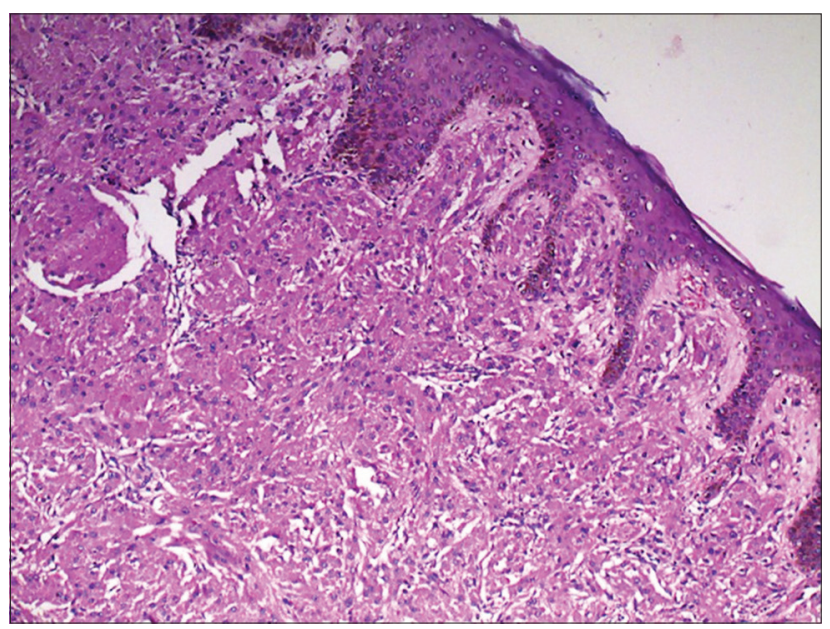

Figure 2: Broad fascicles of large, polygonal, tumor cells arranged in nests or sheets infiltrating the dermis and dermal structures. (H\& E, x 10).

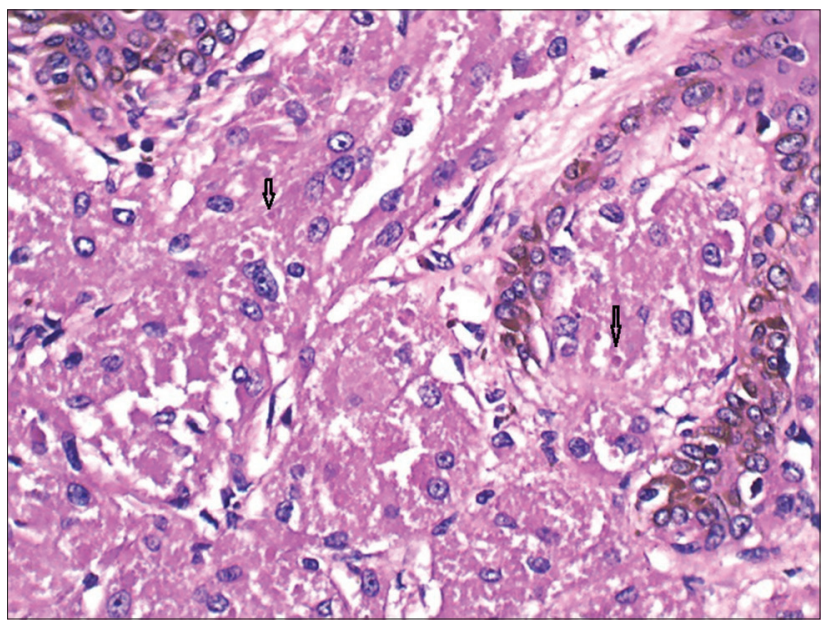

Figure 3: The tumor cells containing round-to-oval nuclei and small, eosinophilic granules uniformly filling the cytoplasm. (H \& E, x 40) and eosinophilic ovoid bodies (pustulo-ovoid bodies of milian) are surrounded by a clear halo. (arrow). 
fulfilling $\geq 3$ criteria were classified as malignant, having one or two criteria as atypical and cases displaying none of the 6 criteria were classified as benign GCT.

Clinical picture is usually simulated by dermatofibroma, fibroxanthoma, lipoma, keratoacanthoma, neurofibroma, leiomyoma and leiomyosarcoma which needs to be ruled out on histopahologic evaluation [1-4]. On histopathology, H \& E staining of sample of GCT of skin characteristically reveal non-encapsulated, irregular sheets of large round or polygonal cells with indistinct cytological borders containing abundantly eosinophilic, granular, pale staining cytoplasm and centrally or eccentrically located small, round or oval nuclei with fine chromatin and inconspicuous nucleoli $[2-4,8]$. The granularity of cytoplasm is due to massive accumulation of lysosomes which may sometimes be larger and surrounded by a clear halo called 'pustulo-ovoid bodies of Milian' $[3,8]$. Occasionally, cytological atypia, nuclear polymorphism and prominent nucleoli may be present. Nonspecifically, epidermis is usually hyperplastic and may show downward proliferation forming horn pearl due to pseudocarcinomatous hyperplasia [5]. Other diseases which also needs to be differentiated by histopathology are rhabdomyoma, rhabdomyosarcoma, alveolar soft tissue sarcoma, schwannoma, paraganglioma, hibernoma and melanoma. IHC further aids in the correct diagnosis of GCT as granular cells are positive for S-100, neuron specific enolase, vimentin, periodic acid-schiff, inhibin- $\alpha$, protein gene product $9.5 \&$ CD 68 and negative for EMA, cytokeratin, desmin, myogenin, smooth muscle actin and HMB-45 [9].

FNAC should be done to make preoperative diagnosis and plan for wide local excision with safe margin due to poorly defined margins [3]. Further follow up is advised to the patients to look for any recurrence and malignant transformation. Adjuvant radiotherapy and chemotherapy may be tried in case of recurrent and metastatic forms of GCT respectively [10].

\section{CONCLUSION}

Having distinctive microscopic features, histopathological examination should always be done in case of any doubtful dermal soft tissue tumour to prevent the misdiagnosis of granular cell tumour and it is better be completely excised if accessible.

\section{Consent}

The examination of the patient was conducted according to the Declaration of Helsinki principles.

\section{ACKNOWLEDGEMENTS}

The authors sincerely thank Dr. Uday Khopkar for their contribution by giving valuable suggestion for the histopathological diagnosis.

\section{REFERENCES}

1. Korambayil PM. Granular cell tumour of the hand. Indian J Plast Surg. 2012;45:1602.

2. Loncar B, Marjanović K, Pauzar B, Staklenc B. Granular cell tumorclinically presented as lymphadenopathy. Coll Antropol. 2010;34:2613.

3. Chung SY, Noh WC, Jin MS, Lee SS, Koh JS. Fine needle aspiration cytology of granular cell tumor in breast -A case report. Korean J Cytopathol. 2007;8:15760.

4. Sung JW, Choi JH. Imprint cytology of granular cell tumorA case report. Korean J Cytopathol. 2007;8:17074.

5. Bielejeski TR. Granularcell tumor (myoblastoma) of the hand. Report of a case. J Bone Joint Surg Am. 1973;55:8413.

6. Golchai J, Zargari O, Paknejadi MB. Multiple granular cell tumor in a teenager: Report of a case and review of the literature. Acta Med Iran. 2004;42:22831.

7. Fanburg-Smith JC, Meis-Kindblom JM, Fante R, Kindblom LG. Malignant granular cell tumor of soft tissue: Diagnostic criteria and clinicopathologic correlation. Am J Surg Pathol. 1998;22:779-94.

8. Nasit JG, Chauhan S, Dhruva G. Granular cell tumor of hand presenting as subcutaneous nodule mimicking dermal adnexal tumor: A diagnosis by cytology. Indian Dermatol Online J. 2013;4:336

9. Weber-Cappuis K, Wildmann JJ, Kapanci Y. Histologic and immunohistochemical profiles of benign granular cell tumors. Report of 41 cases. Ann Pathol. 1995;15:198-202.

10. Kanat O, Yalcinkaya U, Akbunar T, Kurt E, Evrensel T, Manavoglu O. Gemcitabine plus paclitaxel may be a promising chemotherapy regimen for metastatic granular cell tumour. Clin Oncol (R Coll Radiol). 2008;20:93-6.

Copyright by Anup Kumar Tiwary, et al. This is an open access article distributed under the terms of the Creative Commons Attribution License, which permits unrestricted use, distribution, and reproduction in any medium, provided the original author and source are credited.

Source of Support: Nil, Conflict of Interest: None declared. 